\title{
When positive is negative: The moderating role of DT on the relationship between micro-daily events and counterproductive work behavior
}

\section{Daniel Silva}

Instituto Politécnico de Tomar: Instituto Politecnico de Tomar

Ana Junça-Silva ( $\sim$ analjsilva@gmail.com )

* Instituto Universitário de Lisboa (ISCTE-IUL), Lisboa, Portugal https://orcid.org/0000-0001-6341-9771

\section{Research Article}

Keywords: Micro-daily events, Dark triad, Counterproductive work behavior

Posted Date: April 6th, 2021

DOI: https://doi.org/10.21203/rs.3.rs-271080/v1

License: (c) (i) This work is licensed under a Creative Commons Attribution 4.0 International License.

Read Full License 


\section{Abstract}

The workplace is a context, in which, individuals experience diverse types of micro daily events. Taking into account the personality traits, emotions vary, as does the perception of micro daily events. This study examined the three dimensions of the dark triad personality (machiavelism, psychopathy, and narcissism) as moderators of the relationship between micro-daily events, positive and negative, and counterproductive work-related behaviors. To achieve this goal, 205 working adults took part in this study. The results showed that: (1) daily micro-events predicted CWB's, in particular, when the ratio of daily micro-events was positive, the CWB's decreased; (2) the dark triad moderated the relation between micro daily-events and CWB's, such that CWB's decreased as the ratio of daily micro-events increased for individuals with high and moderate DT levels. Such results proved to be fundamental for a better understanding of the behavior of employees in organizations, as well as the impact of daily events in the organizational environment. The implications for theory and practice were discussed.

\section{Introduction}

Micro-daily events at work appear to be a relevant predictor of diverse work-related attitudes and behaviors. The affective events theory (AET; Weiss, \& Cropanzano, 1996) has explored such events and states that these kinds of events arouse positive or negative affective reactions that, in turn, will influence work-related attitudes and behaviors (Cropanzano \& Dasborough, 2015; Lazarus \& Folkman, 1984), such as job performance (Junca-Silva et al., 2017).

The AET also states that personality plays a moderating role in this model, such that diverse traits will buffer or maximize the impact of daily events on affect and job-related outcomes (Weiss, \& Cropanzano, 1996). For instance, optimism has been found to buffer the negative effects of daily hassles on wellbeing (Lench, \& Ditto, 2008). Some big five have also been found to influence the link events-affective reactions (Sahin, \& Cetin, 2017). In a similar vein, several studies have shown that personality traits, such as positive and negative affectivity, are also moderators of the relation between affective events and affect (e.g., Glaso et al., 2011). So, these traits, depending on the work context, and on the events occurred, can influence performance (e.g., Glasø, et al., 2011) and also several job-related behaviors (e.g., Reynolds et al., 2020).

Despite these evidence, empirical studies have been focused on the positive aspects of the personality, giving some emphasis to the big five (e.g., oppeness) (Costa, \& Mcrae, 1992; Lee \& Ashton, 2005). However, the dark side of the personality has been ignored on these kinds of research. Notwithstanding, it is important to consider the dark side of the personality within organizational context, as it is hard to find organizations that do not suffer from this patology (Lučić, 2013). This organizational patology has, in its genesis, the negative work-related behavior of their employees. This negative work-related behavior is related to the dark triad (DT), a set of three personality traits considered to be socially aversive: subclinical psychopathy, narcissism and machiavellianism. DT has consistently been associated to negative or counterproductive work behaviors (CWB) (e.g., O’Boyle, Forsyth, Banks \& McDaniel, 2012). 
Counterproductive behaviors are deliberate actions that harm the organization or its members (O'Boyle, Forsyth, \& O'Boyle, 2011). Such negative behaviors can be translated into robberies, fall of leaders, bad organizational policies, mobbing, manipulation, sadism, among others. These behaviors affect, directly or indirectly, individuals and the organizations, through the negative affective reactions and the subsequent insatisfaction.

Although DT has its importance for individual, so far as we know, there are not studies exploring its effects at work (e.g., O'Boyle, et al., 2011). For example, no study has explored DT within the framework of AET, and as such, there are no studies analyzing the effect of DT on the relationship between microdaily events and CWB. With the aim of fulfilling this gap and to improve the understanding of this problem in the workplace, this study aims to analyze the impact that DT may have on the relationship between micro-daily events and CWB.

\section{Theoretical Framework: The Affective Events Theory}

The workplace is known for being one of the biggest affective environments (Ashkanasy, \& Humphrey, 2011), in which micro-daily events are present day to day, arousing affective reaction on employees. The AET has explored such events and analyzed its major effects (Weiss, \& Cropanzano, 1996). It states that the work environment is filled with job conditions that promote the occurrence of such events. These kinds of events arouse, positive or negative, affective reactions that, in turn, influence work-related attitudes (e.g., job satisfaction) and behaviors (e.g., job performance, or organizational citizenship behaviour) (Junça-Silva, et al., 2017). These micro-events are considered to be affective as they trigger affective reactions from employees (e.g., sadness, happiness) (Junça-Silva, et al., 2017).

Micro-daily have been defined as daily hassles, when they trigger negative affective reactions, and daily uplifts when the affective reaction is positive. Daily hassles are the tiny things that somehow irritate, frustrate or distress individuals (Ashkanasy, et al., 2014). Some examples of daily hassles are sexual harassment, receiving negative feedback, receiving a feedback that is perceived as unfair or inadequate, gossip, lack of resources to perform the job, among others (Junça-Silva, et al., 2020). On the other hand, daily uplifts are the positive daily experiences that will enhance the sense of individuals' well-being and satisfaction (Cropanzano \& Dasborough, 2015). Some examples of daily uplifts are receiving a positive feedback, receiving a compliment from someone at work, to make some positive and deliberate breaks at work, receiving some reward (formal or informal) regarding job performance, among others (Junça-Silva, et al., 2020).

The cognitive appraisal theory also states that the affective reactions prompted by micro-daily events are influenced by the cognitive evaluation that an individual has about what has occurred (Lazarus, 1999). Therefore, the same event may trigger diferente affective reactions, from individual to individual, and from moment to moment. So, based on this theory, it is not the event per se that triggers the affective reaction, but is the event' interpretation that is responsible for it. Moreover, the cognitive evaluation has a role that may either, buffer or booster the arousal of the affective reaction (Kiffin-Petersen, et al., 2012). 
Additionally, there are also factors that may influence the relation between micro-daily events and affective reactions, such as the personality traits (e.g., Weiss, \& Cropanzano, 1996). Weiss and Cropanzano (1996), also refer to the existence of "personality traits that predict general emotional tendencies in individuals" (pp. 12). These personality traits are divided into positive affectivity, that are translated into individuals with a trend to be excited, sociable and often in a good mood, and negative affectivity, associated to individuals more stressed and unhappy, focusing on the negative side of things (Weiss \& Cropanzano, 1996). It is noteworthy the importance that personality traits have on the affective state triggered by such events, as well as its length, and permanence throughout the day, both at work and at home. Therefore, it is evident the impact that the personality traits have, both on the events' cognitive evaluation, and on the affective and behavioral reaction to them.

Micro-daily events appear to predict work-related behaviors. For instance, Junca-silva et al. (2020) demonstrated that micro-daily events predicted job performance, at both between and within level. Daily events at work were also found to be predictors of creativity (Amabile, et al., 2005) and organizational citizenship behaviors (Spence, et al., 2011). Despite the relevance of micro-daily events for behaviors at work, there are no studies exploring if micro-daily events predict CWB's. However, because micro-daily events are proximal causes of diverse work-related behaviors, we expect that:

\section{$\mathrm{H} 1 \mathrm{a}$}

Micro-daily events are negatively related to CWBI.

\section{$\mathrm{H} 1 \mathrm{~b}$}

Micro-daily events are negatively related CWBO.

\section{The Dark Triad}

Recently, there has been a growing interest in the analysis of the personality traits in the organizational settings, with a special focus on dark side of the personality. With respect to this, Paulhus and Williams (2002) suggest the existence of a set of three personality traits (Machiavellianism, psychopathy and narcissism) defined as the DT. DT has been shown to be quite harmful to the workplace, in particular, when the individual has high levels of these three traits.

DT are different from clinical pathologies because these traits do not reflect an inadaptability in daily life and are included in socially accepted behavioral patterns (Hogan \& Hogan, 2001).

Individuals high in Machiavellianism are characterized by their antipathy, low levels of affectivity, by their own and distorted view of morality that comes from their desire to manipulate, lie and exploit others, with an exacerbated focus on their goals (Christie \& Geis, 1970; Wu \& LeBreton, 2011). This trait is defined by three sets of interrelated values: (1) a belief based on manipulative tactics in dealing with others; (2) a cynical view of human nature, and (3) an amoral perspective that overates convenience, over the principle (O'Boyle et al., 2012). Such psychological norms lead to a range of negative behaviors. For example, 
machiavellians are prone to take revenge on others (Nathanson, 2008) and to lie, more regularly, to people in their inner circle (friends, family, etc.) (Kashy \& DePaulo, 1996). Diverse studies have shown the negative consequences of machiavelianism in the work context, for example, antiethic (Treviño, 2003) and manipulative leaders (Hurley, 2005), and low levels of job performances (Molm, 2010), among others.

On the other hand, psychopathy can be seen as a trait, or as a personality disorder. It is characterized by impulsivity, together with an immediate suppression of personal needs (Cleckley, 1976; Hare, 1999), a constant look for feeling and experiencing emotions, combined with low levels of empathy and anxiety (Spain, et al., 2014), and a self-belief in their own superiority and self-promotion trends (Lynam \& Widiger, 2007). With respect to this, Jones and Paulhus (2014) refer that psychopathy is based on two key elements: (1) the lack of affection (insensitivity and lack of empathy) and (2) an absence of self-control (impulsivity), that is, it reflects a lack of concern, both with people or with the social regulation mechanisms, as well as an absence of guilt and/or remorse, when their actions harm third parties (O'Boyle, et al., 2012). As a result, psychopaths are immune to anxiety and fear to a certain extent, becoming less vulnerable to embarrassment (Hare, 1999) and, consequently, fail to learn from their mistakes. Psychopathy is the most malevolente trait of DT. Although there are few studies on the impact of psychopathy in the workplace, there is evidence that psychopaths tend to engage in interpersonal conficts (Boddy, 2014), bullying (Van Geel, et al., 2107), abusive supervision (Boddy, 2010) and in illegal and criminal activities (Hare \& Neumann, 2009).

Regarding narcissistic personality, this is marked by a sense of grandiosity, a lack of empathy (Smith, \& Lilienfeld, 2013), by the exaggeration imprinted on their achievements (exaggerated view of their own "self"), the rejection of criticism, the difficulty to be commited and the continuous search for relationships with individuals who admire and/or idolize themselves (Resick, et al., 2009). It also includes an inflated view of oneself, of their own success, control, self-admiration and self-love, and the need that this selflove is reinforced by third parties (O'Boyle et al., 2012). Narcissism has received some attention regarding its consequences in the workplace (e.g., Campbell, et al., 2011). For example, studies have shown that narcissism at work leads to poor performances (Judge, et al., 2006), job insatisfaction (Soyer, et al., 2001), and toxic leaderships (Schmidt, 2008). Therefore, we expect that:

H2a: DT is positevely related to CWBI.

H2b: DT is positevely related to CWBO.

\section{DT and counterproductive work behaviors}

One of the major consequences of DT in the workplace is CWB (e.g., Wu \& Lebreton, 2011). Several studies demonstrate that the manipulation inherente to Machiavellianism, the narcissism' sense of entitlement, and the antisocial tendencies of psychopathy are CWB triggers (O'Boyle et al., 2011).

These behaviors are deliberate actions aimed to damage employees and/or the organization (O'Boyle et al., 2014). In general, CWBs may be triggered due to (1) personal factors (due to traits, or disorders, or due 
to psychological problems), and (2) organizational factors (due to the perception of unfairness, incompatibility with managers, or the organizational environment).

There are two forms of CWBs: (1) CWB towards the organization occurr when directed to the organization (CWB-O), and (2) CWB towards individuals occur when directed to employees (CWB-I). Examples of CWBIs are physical and verbal aggression, abuse of information (personal or organizational towards third parties) and antipathy towards other employees and customers. On the other hand, excessive pauses, misuse of organizational property, theft, purposeful error are examples of CWB-O (Spector, et al., 2006).

CWB's have relevant and negative consequences for organizations. It is estimated that organiations lose billions of dollars per year, due to CWBs (Bennett, \& Robinson, 2000). These types of deviant behaviors are based on deviant personality traits, such as DT traits (Kish-Gephart, et al., 2010).

Moore and colleagues (2012) reported that machiavelliism is closely related to unethical behaviors and to several transgressive behavioral trends, including antisocial behavior, lying and manipulation.

Machiavellians have no moral limitations, which makes them to pursue their own interests, without any kind of self-censorship. Given its focus and moral disengagement, it is not surprising that there is a positive relationship between high traits of Machiavellianism and unethical behavior (Hegarty \& Sims, 1979). Due to the absence of emotional involvement in interpersonal relationships, communication tends to be less controlled, more impulsive and irresponsible, without taking into account their negative impact on others (Skinner, 1988). As a result, machiavellians tend to engage in communicative CWB's (such as, verbal aggression or rumors) (Wu \& Lebreton, 2011). So, we hypothesize that:

$\mathrm{H} 3 \mathrm{a}$ : Machiavellianism moderates the relationship between micro-daily events and $\mathrm{CWBI}$, such that the higher the machiavellianism, the weaker the relationship between micro-daily events and the CWBI.

$\mathrm{H} 3 \mathrm{~b}$ : Machiavellianism moderates the relationship between micro-daily events and $\mathrm{CWBI}$, such that the higher the machiavellianism, the weaker the relationship between micro-daily events and the CWBO.

On the other hand, narcisistics tend to interpret criticism and insults as threats to themselves, which increases when these criticisms and insults are made in public. This increased sensitivity to criticism becomes a threat to the self, triggering anger that, in turn, leads to CWB's (Spector, 2011). Wu and Lebreton (2011) also argue that narcissists tend to see themselves as victims which, in turn, increases their vulnerability to engage in negative interactions. This set of negativism and feelings of unfairness, increases the likelihood of engaging in CWB's, such as hostile behaviors, obstructionism or open aggression directed to others. When narcisistics interprets interactions as transgressions, it may lead them to absenteeism, retaliatory or fraudulent behavior (Perri, 2013). Wu and Lebreton (2011) also point out that narcissists tend to do whatever it takes for their self-aggrandizement. Their sense of superiority, rebellion and the self-belief of being special, leads them to totally disregard others. Because they have a negative and inferior view of others, they tend to dominate and explore them, and therefore demonstrate their own superiority (Wu \& Lebreton, 2011). Since narcissists have this special view of themselves, they 
do not believe or accept that their behavior is negative, which increases the likelihood of performing CWBs during their constant search for self-improvement. So, we expect that:

$\mathrm{H} 4 \mathrm{a}$ : Marcisism moderates the relationship between micro-daily events and CWBI, such that the higher the narcisism, the weaker the relationship between micro-daily events and the CWBI.

H4b: Marcisism moderates the relationship between micro-daily events and CWBI, such that the higher the narcisism, the weaker the relationship between micro-daily events and the CWBO.

Regarding psychpaths, according to Wu and Lebreton (2011), they not only get satisfaction from harming others but use this same behavior to achieve their own goals. This occurs to divert attention from a specific task. Thus, hostility between colleagues not only allows to divert attention from a task, but also facilitates the achievement of its own goals. Wu and Lebreton (2011) stated that psychopaths believe that social norms and rules do not apply to themswlves, so they usually do not assume responsibility for their actions. Additionally, because psychopaths are individuals without remorse and conscience, who like to take risks, it can lead them to performe risky and compulsive acts, such as unsafe behaviors, which can, for example, lead to the destruction of organizational property, inappropriate physical and verbal behaviors or others that arise as an immediate response to negative events (Wu \& Lebreton, 2011). So, it is expected that (Fig. 1):

H5a: Psychopathy moderates the relationship between micro-daily events and CWBI, such that the higher the psychopathy, the weaker the relationship between micro-daily events and the CWBI.

H5b: Psychopathy moderates the relationship between micro-daily events and CWBI, such that the higher the psychopathy, the weaker the relationship between micro-daily events and the CWBO.

\section{Method}

\section{Participants}

Overall, participated in this study 205 working adults, in which most of them were women $(79.5 \%)$. Participants were aged between between 18 and 65, and most of them were aged between 35 and 54 years old (56.4\%).

From the overall participants, the majority has children (60.5\%).

$59.5 \%$ of the participants is graduated, and also described them to be in a mean-low socioeconomic level. Most participants are in their organization for at least three years (32.6\%), followed by those who are in the organization for more thean ten years (33.7\%), and also by those who are there between four and nine years (33.7\%).

\section{Measures}

To measure micro-daily events, we used the Scale for Daily Hassles and Uplifts at Work (SDHUW; JunçaSilva et al., 2020). This scale measures the frequency of micro-daily events at work: daily hassles (10 
itens, e.g., "Someone was rude for me at work") and uplifts (eight itens, e.g., "I received positive feedback on my performance").

Participants answered in a five-point Likert scale, regarding the daily events occurred at work in the past seven days (1-never occured; 5-occurred more than four times).

Cronbach'alpha was .88 for the daily uplift dimension, and .86 for the daily hassle dimension. Overall, the scale presented an a of .88. To test our hypotheses, we created a ratio between daily uplifts and daily hassles. This ratio allows us to identify the proportionality of the daily uplifts in function of the daily hassles. That is, when the ratio is higher than one, it means that the daily uplifts occurred more frequently than the daily hassles did.

To measure $D T$, we used the Dirty Dozen (Jonason, \& Webster, 2010). This scale includes 17 itens, divided in three dimensions: narcissism (e.g., "I tend to manipulate others to get what I want"), psychopathy (e.g., "Usually, I don't feel remorse") and machiavellism (e.g., "I tend to look for status or prestige").

Participants anwered on a five-point Likert scale (1-Totally disagree; 5-Totally disagree).

Cronbach'a was .91 for the overall scale and ranged between .89 and .92 for the subscales (narcissism $=.89 ;$ psychopathy $=.90$, and machiavelliism $=.92$ ).

To measure CWB we used the CWB Workplace Deviance Scale (Bennett, \& Robinson, 2000).

The scale includes 19 items that evaluate the two CWB dimensions: CWB-I ("I joked with someone at work") and CWB-O ("I took something from work without permission").

Asnwers were given on five-point Likert scale (1 - never; 5 - always). Overall, the scale presented a Cronbach a of .93 , ranging from .91 for the CWB-I dimension, and .94 for the CWB-O dimension.

\section{Procedure}

Participants completed an online questionnaire.

This was emailed to participants asking them to participate in a "study about daily events at work'. From the 300 emails sent, there were 205 valid responses, which means a $68 \%$ response rate. The confidentiality and anonymity, of the participants, was warranted before they agree to participate in the study.

\section{Data analysis}

Firstly, we calculated the descriptive statistics and bivariate correlations among the variables under study. For data analysis, we used SPSS v. 27.0. The moderating model was tested by using Hayes (2018) PROCESS macro (Model 1). The $95 \%$ bias-corrected confidence interval from 5000 resamples was generated by bias-corrected bootstrapping method to examine the significance of moderation effect.

\section{Results}




\section{Preliminary analyses}

Means, standard deviations, and correlations between the variables are showed in Table 1. Of the overall sample, participants reported a positive ratio of micro daily events $(M=1.24 ; S D=.52)$. The highest $D T$ trait was narcissism $(M=2.60 ; S D=1.12)$, followed by machiavellianism $(M=1.92 ; S D=1.14)$, and then psychopathy $(M=1.24 ; S D=.52)$. The more performed CWBs were CWB-O $(M=1.68 ; S D=.84)$ and then CWB-I $(M=1.49 ; S D=.75)$. Moreover, all the variables were significantly related with each other.

Table 1

Means, standard deviations, and correlations between the variables.

\begin{tabular}{|c|c|c|c|c|c|c|c|c|}
\hline & $M$ & $S D$ & 1 & 2 & 3 & 4 & 5 & 6 \\
\hline 1.Micro-daily events & 1.24 & .52 & $(.88)$ & & & & & \\
\hline 2.CWB-O & 1.68 & .84 & $-.35^{\star \star}$ & $(.94)$ & & & & \\
\hline 3.CWB-I & 1.49 & .75 & $-.29 \star \star$ & $.85^{\star \star}$ & $(.91)$ & & & \\
\hline 4.Narcisism & 2.60 & 1.12 & $-.30 \star \star$ & $.62^{\star \star}$ & $.57^{\star \star}$ & $(.89)$ & & \\
\hline 5.Machiavellianism & 1.92 & 1.14 & $-.25^{\star \star}$ & $.76^{\star *}$ & $.72 \star \star$ & $.66^{\star \star}$ & $(.92)$ & \\
\hline 6.Psychpaty & 1.79 & .97 & $-.25^{\star \star}$ & $.73^{\star \star}$ & $.68^{* *}$ & $.57 * \star$ & $.72^{\star \star}$ & $(.90)$ \\
\hline
\end{tabular}


Table 2

The moderating role of DT in the relationship between micro-daily events and CWBI's.

\begin{tabular}{|c|c|c|c|}
\hline $\begin{array}{l}\text { Variables } \\
\text { CWBI }\end{array}$ & $\boldsymbol{\beta}$ & $S E$ & $\mathrm{LLCl}-\mathrm{ULCl}$ \\
\hline Micro-daily events & $-.32 * \star$ & .06 & $-.45,-.19$ \\
\hline Machiavellianism & $.31 \star \star$ & .03 & $.24, .38$ \\
\hline (eventsmaq.) & $-.55^{\star \star}$ & .07 & $-.69,-.41$ \\
\hline \multicolumn{4}{|c|}{$R^{2}=.65, F_{(3,201)}=122.08$} \\
\hline Micro-daily events & $-.29 * \star$ & .07 & $-.43,-.15$ \\
\hline Psichopathy & $.33^{\star *}$ & .05 & $.24, .42$ \\
\hline (eventospsic.) & $-.57 * \star$ & .09 & $-.75,-.38$ \\
\hline \multicolumn{4}{|c|}{$R^{2}=.57, F_{(3,201)}=87.74$} \\
\hline Micro-daily events & $-.34^{\star \star}$ & .08 & $-.49,-.18$ \\
\hline Narcissism & $.27^{\star \star}$ & .04 & $.20, .35$ \\
\hline (events*narc.) & -.58 ** & .08 & $-.73,-.43$ \\
\hline \multicolumn{4}{|c|}{$R^{2}=.49 \mathrm{~F}_{(3,201)}=64.69$} \\
\hline Notes: $N=205 ;{ }^{\star} p$ & $5 ; * \star p$ & & \\
\hline
\end{tabular}

\section{Hypothesis Testing}

\section{The effect of micro-daily events on CWB}

Hypothesis 1 a predicted that micro-daily events would be negatively related to CWBI. As expected, microdaily events presented a moderate correlation with CWBI $(r=-.29, p<.01)$. Moreover, the results of a linear regression also showed that micro-daily events predicted CWBI $\left(\beta=-.30, t(204)=-4.45 ; p<.001 ; R^{2}\right.$ $=.09$ ). therefore, $\mathrm{H} 1 \mathrm{a}$ was supported by the data.

Hypothesis $1 \mathrm{~b}$ expected that micro-daily events would be negatively related to CWBO. First, results from the correlations showed that micro-daily events were negatively related to CWBO $(r=-.35, p<.01)$. Plus, the results of a linear regression also showed that micro-daily events predicted CWBO $\left(\beta=-.35, t_{(204)}=\right.$ $\left.-5.32, p<.001 ; R^{2}=.12\right)$. As such, $\mathrm{H} 1 \mathrm{~b}$ was also supported by the data.

\section{The effect of DT on CWB}


Hypothesis 1a predicted that DT would be positively related to CWBI. As expected, all the DT traits presented strong correlations with $\mathrm{CWBI}(.57>r<.72, p<.01)$. Moreover, the results of a linear regression also showed that overall DT predicted CWBI $\left(\beta=.75, t_{(204)}=16.25, p<.001 ; R^{2}=.56\right)$. therefore, $\mathrm{H} 2 \mathrm{a}$ was supported by the data.

We also analyzed the specific direct influence of each DT trait on CWBI. The results also confirmed that all DT traits significantly and positively predicted CWBI (machiavellianism: $\beta=.41, t_{(204)}=5.61, p<.001$; psychopathy: $\beta=.31, t_{(204)}=4.70, p<.001$; narcissism $\left(\beta=.12, t_{(204)}=1.91, p<.05\right)$.

Hypothesis $1 \mathrm{~b}$ predicted that DT would be positively related to CWBO. As expected, all the DT traits presented strong correlations with CWBI $(.62>r<.76, p<.01)$. Moreover, the results of a linear regression also showed that overall DT predicted CWBI $\left(\beta=.80, t_{(204)}=19.23, p<.001 ; R^{2}=.64\right)$. Therefore, H2b was supported by the data.

Following what we made with CWBI, we analyed the specific influence of each DT trait on CWBO. The results also showed that all DT traits significantly and positively predicted CWBO (Machiavellianism: $\beta$ $=.40, t_{(204)}=6.00, p<.001$; psychopathy: $\beta=.36, t_{(204)}=6.01, p<.001$; narcissism $\beta=.15, t_{(204)}=2.65, p$ $<.01)$.

\section{The moderating effect of DT between micro-daily events and CWB}

Machiavellianism. The hypothesis 3 predicted that machiavellianism would moderate the relationship between micro-daily events and CWBI $(\mathrm{H} 3 a)$ and CWBO $(\mathrm{H} 3 \mathrm{~b})$, such that the higher the machiavellianism, the weaker the relationship between micro-daily events and CWB). To test these hypotheses, we conducted two moderations with PROCESS (model 1, Hayes, 2018).

Regarding $\mathrm{H} 3 \mathrm{a}$, the results showed a significant interaction effect of machiavellianism with micro-daily events in predicting $\mathrm{CWBI}\left(B=-.55, \beta=.07, \Delta R^{2}=.11, p<.01\right)$. Simple slope analysis (Dearing, \& Hamilton, 2006) found that micro-daily events showed a significant relationship with CWBI in higher levels of machiavellianism (i.e., 1 SD above the mean) (simple slope $=-.95, \beta=.12, p<.01, \mathrm{IC} 95 \%[-1.18$, - .73]), and in mean levels of Machiavellianism (simple slope $=-.32, \beta=.06, p<.01, \mathrm{IC} 95 \%[-.44,-.19]$ ). However, and even tough significant, the relationship between micro-daily events and lower levels of machiavellianism (i.e., 1 SD below the mean) appears to increase CWBI (simple slope $=.19, \beta=.08, p$ $<.01$, IC 95\% [.03, .34]) (see Fig. 2 and Table 1). Therefore, h3a was supported by the data.

Regarding $\mathrm{H} 3 \mathrm{~b}$, the results demonstrated the existence of a significant interaction effect of machiavellianism and micro-daily events in predicting CWBO $\left(B=-.58 \beta=.07, \Delta R^{2}=.09, p<.01\right)$. Simple slope analysis (Dearing, \& Hamilton, 2006) found that micro-daily events showed a significant relationship with CWBO in higher levels of machiavellianism (i.e., 1 SD above the mean) (simple slope = $-1.08, \beta=.12, p<.01, \mathrm{IC} 95 \%[-1.32,-.85]$ ), and in mean levels of machiavellianism (simple slope $=-.42, \beta$ $=.07, p<.01$, IC 95\% [-.55, - .29]), but not significant in lower levels of machiavellianism (i.e., 1 SD below 
the mean)(simple slope $=.12, \beta=.08, p>.05$, IC $95 \%[-.04, .32]$ ) (see Fig. 3, Table 3). Therefore, h3b was supported by the data.

Table 3

The moderating role of DT in the relationship between micro-daily events and CWBO's.

\begin{tabular}{|c|c|c|c|}
\hline $\begin{array}{l}\text { Variables } \\
\text { CWBO }\end{array}$ & $\beta$ & $S E$ & $\mathrm{LLCl}-\mathrm{ULCl}$ \\
\hline Micro-daily events & $-.42^{\star \star}$ & .07 & $-.55,-.28$ \\
\hline Machiavellianism & $.37 * \star$ & .04 & $.30, .44$ \\
\hline (events*maq.) & $-.58^{\star \star}$ & .07 & $-.72,-.44$ \\
\hline \multicolumn{4}{|c|}{$\mathrm{R}^{2}=.70, \mathrm{~F}_{(3,201)}=157.41$} \\
\hline Micro-daily events & $-.37 \star \star$ & .07 & $-.52,-.23$ \\
\hline Psichopathy & $.44 * \star$ & .04 & $.34, .53$ \\
\hline (events*psic.) & $-.54 \star \star$ & .10 & $-.73,-.35$ \\
\hline \multicolumn{4}{|c|}{$R^{2}=.63, F_{(3,201)}=115.24$} \\
\hline Micro-daily events & $-.44 \star \star$ & .08 & $-.60,-.28$ \\
\hline Narcisissm & $.33^{\star \star}$ & .04 & $.26, .41$ \\
\hline (events*narc.) & $-.62^{\star \star}$ & .08 & $-.77,-.46$ \\
\hline \multicolumn{4}{|c|}{$\mathrm{R}^{2}=.54 \mathrm{~F}_{(3,201)}=81.04$} \\
\hline \multicolumn{4}{|c|}{ Notes: $N=205 ; * p<.05 ;{ }^{* \star} p<.01$} \\
\hline
\end{tabular}

Narcissism. The hypothesis 4 predicted that narcissism would moderate the relationship between microdaily events and CWBI ( $\mathrm{H} 4 \mathrm{a})$ and CWBO $(\mathrm{H} 4 \mathrm{~b})$, such that the higher the narcissism, the weaker the relationship between micro-daily events and CWB.

Regarding $\mathrm{H} 4 \mathrm{a}$, the results showed a significant interaction effect of narcissism with micro-daily events in predicting CWBI $\left(B=-.58, \beta=.08, \Delta R^{2}=.14, p<.01\right)$. Simple slope analysis (Dearing, \& Hamilton, 2006) found that micro-daily events showed a significant relationship with CWBI in higher levels of narcissism (i.e., $1 \mathrm{SD}$ above the mean) (simple slope $=-.98, \beta=.13, p<.01$, IC $95 \%[-1.24,-.73]$ ), and in mean levels of narcissism (simple slope $=-.34, \beta=.08, p<.01$, IC 95\% [-.49, - .18]). However, and even tough significant, the relationship between micro-daily events and lower levels of narcissism (i.e., 1 SD below the mean) appears to increase CWBI (simple slope $=.31, \beta=.10, p<.01$, IC 95\% [.10, .51]) (Fig. 4). So, h4a was supported by the data. 
Regarding $\mathrm{H} 4 \mathrm{~b}$, the results demonstrated the existence of a significant interaction effect of narcissism and micro-daily events in predicting CWBO $\left(B=-.62 \beta=.08, \Delta R^{2}=.13, p<.01\right)$. Simple slope analysis (Dearing, \& Hamilton, 2006) found that micro-daily events showed a significant relationship with CWBO in higher levels of narcissism (i.e., 1 SD above the mean) (simple slope $=-1.13, \beta=.14, p<.01$, IC 95\% [-1.40, $-.87]$ ), and in mean levels of narcissism (simple slope $=-=.44, \beta=.08, p<.01$, IC $95 \%[-.60,-.28]$ ). As observed in the $\mathrm{h} 4 \mathrm{a}$, the same occurred, that is, even tough significant, the relationship between microdaily events and lower levels of narcissism (i.e., 1 SD below the mean) appears to increase CWBO (i.e., 1 SD below the mean) (simple slope $=.25, \beta=.11, p<.05$, IC 95\% [.04, .47]) (Fig. 5). Therefore, h4b was supported by the data.

Psychopaty. The hypothesis 5 predicted that psychopathy would moderate the relationship between micro-daily events and CWBI ( $\mathrm{H} 5 \mathrm{a})$ and CWBO $(\mathrm{H} 5 \mathrm{~b})$, such that the higher the psychopathy, the weaker the relationship between micro-daily events and CWB.

Regarding $\mathrm{H} 5 \mathrm{a}$, the results showed a significant interaction effect of psychopathy with micro-daily events in predicting CWBI $\left(B=-.56, \beta=.09, \Delta R^{2}=.08, p<.01\right)$. Simple slope analysis (Dearing, \& Hamilton, 2006) found that micro-daily events showed a significant relationship with CWBI in higher levels of psychopathy (i.e., $1 \mathrm{SD}$ above the mean) (simple slope $=-.84, \beta=.13, p<.01$, IC 95\% [-1.09, -.59$]$ ), and in mean levels of psychopathy (simple slope $=-.29, \beta=.07, p<.01$, IC 95\% $[-.43,-.15]$ ). But not in lower levels of psychopathy (i.e., 1 SD below the mean) (simple slope $=.16, \beta=.09, p>.05$, IC 95\% [-.01, .33]) (Fig. 5). So, h5a was supported by the data.

Regarding $\mathrm{H} 5 \mathrm{~b}$, the results demonstrated the existence of a significant interaction effect of psychopathy and micro-daily events in predicting $\operatorname{CWBO}\left(B=-.54 \beta=.10, \Delta R^{2}=.06, p<.01\right)$. Simple slope analysis (Dearing, \& Hamilton, 2006) found that micro-daily events showed a significant relationship with CWBO in higher levels of psychopathy (i.e., 1 SD above the mean) (simple slope $=-.91, \beta=.13, p<.01$, IC 95\% $[-1.16,-.64]$ ), and in mean levels of psychopathy (simple slope $==-.37, \beta=.07, p<.01$, IC $95 \%[-.52$, $-.23]$ ). But not in lower levels of psychopathy (i.e., 1 SD below the mean) (simple slope $=.05, \beta=.09, p$ $>.05$, IC $95 \%[-.12, .23])$ (Fig. 7). So, h5b was supported by the data.

\section{Discussion}

This study'goals were threefold: (1) explore if micro-daily events were negatively related to CWB (CWBI's and CWBO's); (2) analyze if DT were positively related to such behaviors, and (3) analyze the potential moderating role of DT on the link between micro-daily events and CWB.

The results suported our first hypotheses, by demonstrating that micro-daily events were a significant situational predictor of CWBs. Moreover, these relationships were found to be negative, as expected. That is, the higher the ratio of micro-daily events, the less occurrence of CWBI's and CWBO's. This is consistent with other studies (e.g., Junça-Silva, et al., 2020) demonstrating the benefits of experiencing daily uplifts in diverse work-related outcomes, such as, job performance, or work engagement. Matta et al. (2014), in their diary study conducted through 10 days, also showed that daily hassles were closely related to 
negative affective reactions which, in turn, lead to increases in diverse kinds of daily CWB's. So, there is strong evidence that micro-daily events are a strong predictor of diverse forms of CWB's at work.

Second, we proposed that DT would also predict both forms of CWB's. The results were also consistent with what was expected and revealed a positive relationship between DT and CWB's. That is, the higher the DT levels, the more CWB's, performed. To this respect, Wu and Lebreton (2011) also demonstrated the existence of a significant link between each DT trait and deviant behaviors in the workplace, justified by the deviant personality inherent to DT traits. DeShong, et al. (2015) also stated that DT was positively related to CWB's. So, DT is also a strong predictor of these kinds of deviant behaviors at work.

Moreover, when we consider each DT trait individually, the results showed that mahiavellianism appears to be the strongest predictor of both CWB's, followed by the psychopathy, and at last, the narcissism. Although there is not consensus, several studies (e.g., Kanten, et al., 2015) have suggested that machiavellianism and psychopathy are the DT traits that most impact CWB's. Narcissism is seen as the less black trait of DT (Volmer, et al., 2016), however, there are cultural influences that seem to mitigate or exponentiate its impact.

Addionally, our results demonstrated that each DT trait appears to be a moderator in the link micro-daily events and CWB's. Specifically, when the micro-daily events ratio is lower than 1, and the DT is high, the frequency of each form of CWB increases. That is, when the frequency of daily hassles increases, the individuals with the highest levels of DT are those who perform more CWB's. However, for individuals with moderate to high levels of DT traits, this behavioral trend decreases when daily uplits increase. As such, individuals who have the dark personality, when confronted with several daily hassles, see their "dark side" also intensifying, which leads them to incur in more CWB's. This is consistent with the main assumptions of AET (Weiss, \& Cropanzano, 1996), that is the behaviors triggered by micro-daily events, may be positive or negative, depending on the nature of the event occurred, however this is exponentiated in individuals with high levels of DT (Cropanzano \& Dasborough, 2015).

Diverse studies have associated CWB's to aggressive, antisocial and deviant attitudes and behaviors (Neuman \& Baron, 1998), delinquency (Hogan \& Hogan, 1989) retaliation and revenge (Skarlicki \& Folger, 1997). Bies et al. (1997) also state that, the affective perspective is related to CWB's because, affective events at work, by arousing negative affect and thoughts, under the right conditions, can lead to adverse behavioral reactions (CWB's). Thus, affective events are psychological ignitions inducing deviant actions (Wallbott, \& Scherer, 1989). Individuals are active agents of their own experiences, and affective events become triggers that influence certain behaviors (Bies et al., 1997), as is the case with CWB's.

While daily hassles induce tendencies of run away from negative situations, daily uplifts create tendencies of positive actions. Therefore, the greater the frequency of daily uplifts, the greater the likelihood of behaviors that increase and maintain a positive work environment. Plus, when individuals experience daily uplifts, they tend to behave in an altruistic manner in order to maintain a positive state of mind (Isen, 1984). 
Addionally, with the increase in the ratio of micro-daily events, the decrease in CWB's can occur due to the induction of positive affect triggered by these events, which in turn, can buffer the negative affect, typical of DT traits, having, as a consequence, the decrease in CWB's. Furthermore, this can happen also because positive affect promotes the involvement of the individual with the workplace and instigate the search for more positive affect. For example, according to the broaden and build theory (Fredrickson, 2001), the experience of positive affect increases the capacity for momentary thought-action which, in turn, contributes to the enrichment of personal resource, that is, there is a positive spiral, in which positive affect contributes to the individual improvement in the workplace. These assumptions seem to be similar even for individuals with high levels of DT, since a higher ratio of micro-daily events seem to decrease their CWB's.

Unexpectedly, it seems to be the opposite trend when we look at individuals with low levels of DT. That is, the increase in the ratio of micro-daily events, appear to lead these individuals, with lower levels of DT, to increase their CWBI's. However, this trend can only be seen in machiavellianism and narcissism. This pattern was not verified in the psychopathy. This can be justified by the need of having interpersonal interactions, crutial characteristics of machiavellians and narcissists (Volmer, et al., 2016). However, this is not consensual (Spain, \& Harms, 2014) among the researchers.

This pattern of results was also verified regarding CWBO's, however only for narcissism. That is, as the micro-daily events ratio increases, CWBO's tend to increase for individuals with low levels of DT. The justification for these behavioral reactions may lie in the neutralization theory (Sykes \& Matza, 1957). Accordingly, neutralization appears to be a technique that allows individuals to rationalize or justify their immoral or illegal acts (Sykes \& Matza, 1957). This theory is used to understand deviant behaviors and states that a great part of such behaviors does not occur all of the time. That is, people that engage in these kinds of behaviors are not mean in their nature. The theory also notes that individuals drift back and forth between acceptable and deviant behaviors. With respect to this, because most people are not immune to guilt and remorse, they need excuses for the times in which they do drift into offensive or harmful actions. They need some mechanism to allow them to deal with their own guilt and the agent for this rationalization is neutralization. Therefore, neutralization appears to be a defense mechanism through which individuals downplay the repercussions of their behavior. It is a kind of temporary release from society's moral bond with society. By using neutralization, individuals can justify their actions and turn off their internal social-control button. Denying their culpability helps them to deflect the disapproval that they will experience from defying societal norms and societal expectations of what is acceptable behavior. They are regular people who need some way to allay the guilt and blame that they feel for harming another human being, despite their intent (Daigle, 2005). So, individuals with low levels of DT may use neutralization techniques to justify their negative behavior, such as, CWBs.

\section{Theoretical and practical Implications}

This study has sevaral implications for individuals and organizations. First, it is important to understand the relationship between micro-daily events, DT and CWB's because it appears to be relevant to use DT

Page 15/31 
measures in recruitment and selection, once it can avoid dramatical losses for organizations, such as financial losses (resulting from fraud) or denigrating the organizational image (through harassment among employees or discrimination) (Jones, 1997).

On the other hand, it is important to understand how micro-daily events can be used as a socialization strategy to better integrate the newly employees in the organizational context, taking advantage of their added value and mitigating their negative impact.

\section{Limitations and future directions}

Despite the positive features of this study, it has some limitations. First, tha small sample size means that these results should be generalized with caution. Second, the use of self-reported measures may also bias the data, because individuals may not always provide accurate reports. Efforts should be made to further studies, by conducting, for instance, a diary study, in order to obtain more accurate data. Moreover, the sample was mostly feminine, which again limits the generalization of the data. In addition, several studies point to a greater male predisposition to emotional stimuli and CWB's (Bowling, \& Burns, 2015), so a more homogeneous sample, and/or in contrast, being made up only of male individuals, it would be interesting to compare results. Also, the fact that data was collected in just one moment is a limitation. Daily events must be collected at various time points to understand the existing fluctuations. Therefore, future studies could replicate this study through a longitudinal or daily study.

\section{Conclusions}

These results add to the existing literature on micro-daily events, DT traits and its impact on CWBs; to date, this is the first study exploring the role of DT as moderators between micro-daily events and CWBs. The present study addresses a major gap in the current organizational behavior literature; whereas the correlational link between micro-daily events and CWBs has been well established, this is one of the first studies to examine some of the intricacies of this relation.

Addionally, the results point out that it does not matter only those who have high levels of DT traits, but those who appear to have lower levels of such traits, when experiencing more daily uplifts tend to behave in a worst way than the dark personalities do. This behavioral pattern can be explained through the neutralizazion theory, in which individuals rationalize their deviant actions to justify them. On the other hand, the dark personalities appear to benefit with the occurrence of more daily uplifts as it appears to diminishe their CWBs.

\section{Declarations}

i) Conflict of interest statement: The authors declare that they have no conflicts of interest.

ii) Compliance of ethical standard statement: All procedures performed in studies involving human participants were in accordance with the ethical standards of the institutional and/or national research 
committee and with the 1964 Helsinki Declaration and its later amendments or comparable ethical standards.

iii) Informed consent: Informed consent was obtained from all individual participants involved in the study.

iv) data availability: The datasets generated during and analysed during the current study are not publicly available due to the confidentialiy and anonimity of the individuals who participated, but are available from the corresponding author on reasonable request.

\section{References}

Abramis, D. (1994), Relationship of job stressors to job performance: linear or an inverted-U?. Psychological Reports, Vol. 75 No. 1, pp. 547-558.

Allport, G. W. (1937). Personality: A Psychological Interpretation. Oxford, England: Holt.

Amabile, T. M., Barsade, S. G., Mueller, J. S., \& Staw, B. M. (2005). Affect and creativity at work. Administrative science quarterly, 50(3), 367-403. https://doi.org/10.2189/asqu.2005.50.3.367

Ames, R., Rose, P. \& Anderson, C. P. (2006). The NPI-16 as a short measure of narcissism. Journal of Research in Personality, 40, 440-450.

Ashkanasy, N. M. \& Humphrey, R. H. (2011). Current research on emotion in organizations. Emotion Review, 3, 214-224. http://dx.doi.org/10.1177/1754073910391684

Ashkanasy, N. M., Ayoko, O. B. \& Jehn, K. A. (2014). Understanding thephysical environment of work and employee behavior: An affectiveevents perspective. Journal of Organizational Behavior, 35(8), 11691184.http://dx.doi.org/10.1002/job.1973

Barbuto, J. E. Jr. (2001). An alternative scoring method for the motivation sources inventory: a case for ratio analysis. Psychol. Rep. 88, 385-386. doi: 10.2466/pr0.2001.88.2.385

Barbuto, J. E. Jr. \& Scholl, R. W. (1998). Motivation sources inventory: development and validation of new scales to measure an integrative taxonomy of motivation. Psychol. Rep. 82, 1011-1022.

Barrick, M. \& Mount, M. (1991). The Big Five personality dimensions and job performance: A metaanalysis. Personnel Psychology, 44, 1-26.

Bartol, C. R., Bergen, G. T., Volckens, J. S. \& Knoras, K. M. (1992). Women in small-town policing: job performance and stress. Crim. Justice Behav. 19, 240-259.

Bennett, R. J. \& Robinson, S. L. (2000). Development of a measure of workplace deviance. Journal of Applied Psychology, 85, 349-360. 
Berry, C. M., Carpenter, N. C. \& Barratt, C. L. (2012). Do other-reports of counterproductive work behavior provide an incremental contribution over self-reports? A meta-analytic comparison. Journal of Applied Psychology, 97(3), 613-636.

Beutler, L. E., Nussbaum, P. D. \& Meredith, K. E. (1988). Changing personality patterns of police officers. Prof. Psychol. Res. Pract. 19, 503.-507. doi: 10.1037/0735-7028.19.5.503

Bies, R. J., Tripp, T. M. \& Kramer, R. M. (1997). At the breaking point: cognitive and social dynamics of revenge in organizations. In R. A. Giacalone, \& J. Greenberg (Eds.), Antisocial behavior in organizations (pp. 18-36). Thousand Oaks, CA: Sage.

Boddy, C. R. (2010). Corporate psychopaths and organizational type. Journal of Public Affairs, 10, 300312.

Boddy, C. R. (2014). Corporate Psychopaths, Conflict, Employee Affective Well-being and Counterproductive Work Behaviour. Journal of Business Ethics 121, 107-21.

Buffardi, L. E. \& Campbell, W. K. (2008). Narcissism and social networking web sites. Personality and Social Psychology Bulletin, 34, 1303-1314. doi:10.1177/0146167208320061

Bushman, B. J., Baumeister, R. F., Thomaes, S., Ryu, E., Begeer, S. \& West, S. G. (2009). Looking again, and harder, for a link between low self-esteem and aggression. Journal of Personality, 77, 427-446. doi: 10.1111/j.1467-6494.2008. 00553.x

Campbell, W. K. (1999). Narcissism and romantic attraction. Journal of Personality and Social Psychology, 77, 1254 -1270. doi: 10.1016/j.jrp.2006.08.004

Campbell, W. K. \& Foster, J. D. (2007). The narcissistic self: Background, an extended agency model, and ongoing controversies. In C. Sedikides \& S. J. Spencer (Eds.), The Self (pp. 115-138). New York: Psychology Press.

Campbell, W. K., Hoffman, B. J., Campbell, S. M. \& Marchiso, G. (2011). Narcissism in organizational contexts. Human Resource Management Review, 21, 268-284.

Chatterjee, A. \& Hambrick, D. C. (2007). It's all about me: Narcissistic chief executive officers and their effects on company strategy and performance. Administrative Science Quarterly, 52, 351-386. doi:10.2189/asqu.52.3.351

Christie, R. C. \& Geis, F. L. (1970). Studies in Machiavellianism. New York: Academic press.

Cleckley, H. M. (1976). The mask of sanity: An attempt to clarify some issues about the so-called psychopathic personality (5thcollege students via self-report. Journal of Personality Assessment, 88, 205-219. Ed.). St. Louis, MO: Mosby. 
Corry, N., Merritt, R. D., Mrug, S. \& Pamp, B. (2008). The factor structure of the Narcissistic Personality Inventory. Journal of Personality Assessment, 90, 593-600.

Cropanzano R. \& Wright T. A. (2001). When a 'happy' worker is really a 'productive' worker: A review and further refinement of the happy-productive worker thesis. Consulting Psychology Journal: Practice and Research 53: 182-199.

Cropanzano, R. \& Dasborough, M. T. (2015). Dynamic models of well-being: Implications of affective events theory for expanding current views on personality and climate. European Journal of Work and Organizational Psychology, 24(6), 844-847.http://dx.doi.org/10.1080/1359432X.2015.1072245

DeShong, H. L., Grant, D. M. \& Mullins-Sweatt, S. N. (2015). Comparing models of counterproductive workplace behaviors. Personality and Individual Differences, 74, 55-60.

Elliot, R. T. (2010). Examining the relationship between personality characteristics and unethical behaviors resulting in economic crime. Ethical Human Psychology and Psychiatry, 12, 269-276.

Fox, S., Spector, P. E. \& Miles, D. (1999). Counterproductive work behavior (CWB) in response to job stressors and organizational justice: the moderator effect of autonomy and emotion traits. Paper presented at the Annual Meeting of the Society for Industrial and Organizational Psychology, Atlanta.

Fox, S., Spector, P. E. \& Miles, D. (2001). Counterproductive work behavior (CWB) in response to job stressors and organizational justice: Some mediator and moderator tests for autonomy and emotions. Journal of Vocational Behavior, 59, 1-19.

Fredrickson, B. L. (2001). The role of positive emotions in positive psychology: The broaden-and-build theory of positive emotions. American psychologist, 56(3), 218.

Furnham, A. \& Crump, J. (2005). Personality traits, types and disorders. European Journal of Personality, $19,167-184$.

Glas $\varnothing$, L., Vie, T. L., Holmdal, G. R., \& Einarsen, S. (2011). An application of affective events theory to workplace bullying. European Psychologist, 16, 198-208. https://doi.org/10.1027/1016-9040/a000026

Greenberg, J. (1997). The STEAL motive: managing the social determinants of employee theft. In R. A. Giacalone, \& J. Greenberg (Eds.), Antisocial behavior in organizations (pp. 85-108). Thousand Oaks, CA: Sage.

Grijalva, E. \& Newman, D. A. (2015). Narcissism and Counterproductive Work Behavior (CWB): metaanalysis and consideration of collectivist culture, big five personality, and narcissism's facet structure. Applied Psychology: An International Review, 64, 93-126.

Gruys, M. L. \& Sackett, P. R. (2003). Investigating the dimensionality of counterproductive work behavior. International Journal of Selection and Assessment, 11, 30 -41. 
Hare, R. D., (1991). The Hare Psychopathy Checklist - Revised. In Cooke, D.J., \& Michie, C., (1997). An item response theory analysis of the Hare Psychopathy Checklist-Revised. Psychological Assessment, 9 (1), 3-14.

Hare, R. D. (1999). Without conscience: The disturbing word of the psychopaths among us. New York, NY: Guilford

Hare, R. D. \& Neumann, C. S. (2009). Psychopathy: Assessment and forensic implications. Canadian Journal of Psychiatry, 54, 791-802.

Hare, R. D., Harpur, T. D., \& Hemphill, J. F. (1989). Scoring Pamphlet for the Self-Report Psychopathy Scale: SRP-II. Unpublished document, Vancouver, Canada: Simon Fraser University.

Harrison, A., Summers, J. \& Mennecke, B. (2016). The effects of the Dark Triad on unethical behavior. J. Bus. Ethics 153, 53-77. doi: 10.1007/ s10551-016-3368-3

Hastings, S. E., \& O’Neill, T. A. (2009). Predicting workplace deviance using broad versus narrow personality variables. Personality and Individual Differences, 47(4), 289-293. doi:

10.1016/j.paid.2009.03.015

Hegarty, W. H. \& Sims, H. P. (1979). Organizational philosophy, policies, and objectives related to unethical decision behavior: A laboratory experiment. Journal of Applied Psychology, 64(3), 331-338.

Heisler, W. J. \& Gemmill, G. R. (1977). Machiavellianism, job satisfaction, job strain, and upward mobility: some cross-organizational evidence. Psychol. Rep. 41, 592-594.

Hodson, G., Hogg, S. M. \& Maclnnis, C. C. (2009). The role of 'dark personalities' (narcissism, Machiavellianism, psychopathy), Big Five personality factors, and ideology in explaining prejudice. Journal of Research in Personality, 43, 686-690.

Hogan, R. \& Hogan, J. (2001). Assessing leadership: A view from the dark side. International Journal of Selection and Assessment, 9, 40-51.

Hollinger, R. C. (1986). Acts against the workplace: social bonding and employee deviance. Deviant Behavior, 7, 53-75.

Hurley, S. (2005). Social heuristics that make us smarter. Philosophical Psychology, 18, 585-612. doi:10.1080/09515080500264214

Isen, A. M. (1984). Toward understanding the role of affect in cognition. In R. S., Wyer Jr., \& T. K. Srull (Eds.), Handbook of social cognition, vol. 3. Hillsdale, NJ: Lawrence Erlbaum.

Johnson, V. A., Beehr, T. A. \& O’Brien, K. E. (2015). Determining the relationship between employee psychopathy and strain: does the type of psychopathy matter? Int. J. Stress Manag. 22, 111-136, doi: 
Jonason, P. K. \& Ferrell, J. D. (2016). Looking under the hood: the psychogenic motivational foundations of the Dark Triad. Personal. Individ. Differ. 94, 324-331. doi: 10.1016/j.paid.2016.01.039

Jonason, P. K. \& Webster, G. D. (2010). The Dirty Dozen: A concise measure of the dark triad. Psychological Assessment, 22(2), 420-432. https://doi.org/10.1037/a0019265.

Jonason, P. K., Li, N. P., Webster, G. D. \& Schmitt, D. P. (2009). The Dark Triad: Facilitating a short-term mating strategy in men. European Journal of Personality, 23, 5-18. doi:10.1002/per.698

Jonason, P. K., Wee, S. \& Li, N. P. (2015). Competition, autonomy, and prestige: mechanisms through which the Dark Triad predict job satisfaction. Personal. Individ. Differ. 72, 112-116. doi: 10.1016/j.paid.2014.08.026

Jones, D. N. (1997). Doing the wrong things: $48 \%$ of workers admit to unethical or illegal acts. USA Today, Apr 4-6.

Jones, D. N. \& Paulhus, D. L. (2009). Machiavellianism. In M. R. Leary \& R. H. Hoyle (Eds.), Handbook of Individual Differences in Social Behavior (pp. 93-108). New York: Guilford.

Jones, D. N. \& Paulhus, D. L. (2014). Introducing the Short Dark Triad (SD3): a briefmeasure of dark personality traits. Assessment 21, 28-41. doi: 10.1177/1073191113514105

Judge, T. A., LePine, J. A. \& Rich, B. L. (2006). Loving yourself abundantly: Relationship of the narcissistic personality to self- and other perceptions of workplace deviance, leadership, and task and contextual performance. Journal of Applied Psychology, 91, 762-776. doi:10.1037/0021-9010.91.4.762

Junça-Silva, A., Caetano, A. \& Lopes, R. R. (2017). Daily Uplifts, well-Being and performance in organizational settings: The differential mediating roles of affect and work engagement. Journal of Happiness Studies, 18, 591-606.

Junça-Silva, A., Caetano, A. \& Lopes, R. R. (2020). A working day in the life of employees: Development and validation of the scale for daily hassles and uplifts at work. TPM - Testing, Psychometrics, Methodology in Applied Psychology, 27(2), 221-250.

Kanner, A. D., Coyne, J. C., Schaefer, C. \& Lazarus, R. S. (1981). Comparison of two modes of stress measurement: Daily hassles and upliftsversus major life events. Journal of behavioural Medicine, 4(1), 19. http://dx.doi.org/10.1007/BF00844845

Kashy, D. A. \& DePaulo, B. M. (1996). Who lie? Journal of Personality and Social Psychology, 70, 10371051. 
Kiffin-Petersen, S., Murphy, S. A. \& Soutar, G. (2012). The problem-solvingservice worker: Appraisal mechanisms and positive affective experiences during customer interactions. Human relations, 65(9), 1179-1206.http://dx.doi.org/10.1177/0018726712451762

Kish-Gephart, J. J., Harrison, D. A. \& Trevino, L. K. (2010). Bad apples, bad cases, and bad barrels: Metaanalytic evidence about sources of unethical decisions at work. Journal of Applied Psychology, 95, 1-31.

Lazarus, R. S. \& Folkman, S. (1984). Stress, appraisal and coping. New York: Springer.

LeBreton, J. M., Binning, J. F. \& Adorno, A. J. (2006). Subclinical psychopaths. In J. C. Thomas \& D. Segal (Eds.), Comprehensive handbook of personality and psychopathology: Vol. 1. Personality and everyday functioning (pp. 388-411). New York, NY: Wiley.

Lee, K. \& Ashton, M. (2005). Psychopathy, Machiavellianism, and narcissism in the Five-Factor Model and the HEXACO model of personality structure. Personality and Individual Differences, 38, 1571-1582.

Lench, H. C., \& Ditto, P. H. (2008). Automatic optimism: Biased use of base rate information for positive and negative events. Journal of Experimental Social Psychology, 44(3), 631-639.

https://doi.org/10.1016/j.jesp.2007.02.011

Lilienfeld, S. O., \& Andrews, B. P. (1996). Development and Preliminary Validation of a Self-Report Measure of Psychopathic Personality Traits in Noncriminal Population. Journal of Personality Assessment, 66(3), 488-524. doi:10.1207/s15327752jpa6603_3

Lynam, D. R. \& Widiger, T. A. (2007). Using a general model of personality to identify the basic elements of psychopathy. Journal of Personality Disorders, 21, 160-178.

Lyubomirsky, S., King, L. \& Diener, E. (2005). The benefits of frequent positive affect: Does happiness lead to success? Psychological Bulletin 131: 803-855.

MacDonald, K. (1995). Evolution, the 5-factor model, and levels of personality. Journal of Personality, 63, 525-567.

Matta, F. K., Erol-Korkmaz, H. T., Johnson, R. E. \& Biçaksiz, P. (2014). Significant work events and counterproductive work behavior: The role of fairness, emotions, and emotion regulation. Journal of Organizational Behavior, 35(7), 920-944.

Moore, C., Detert, J. R., Klebe Treviño, L., Baker, V. L. \& Mayer, D. M. (2012). Why employees do bad things: Moral disengagement and unethical organizational behavior. Personnel Psychology, 65(1), 1-48.

Morf, C. C. \& Rhodewalt, F. (2001). Unraveling the paradoxes of narcissism: A dynamic self-regulatory processing model. Psychological Inquiry, 12, 177-196. 
Morrison, E. W. (1994), "Role definitions and organizational citizenship behavior: the importance of the employee's perspective", The Academy of Management Journal, Vol. 37 No. 6, pp. 1543-1567.

Nathanson, C. (2008). Exploring the dynamics of revenge (Unpublished doctoral dissertation). University of British Columbia, Vancouver, British Columbia, Canada.

Neuman, J. H. \& Baron, R. A. (1998). Workplace violence and workplace aggression: evidence concerning specific forms, potential causes, and preferred targets. Journal of Management, 24, 391-419.

Noser, A. E., Zeigler-Hill, V. \& Besser, A. (2014). Stress and affective experiences: the importance of dark personality features. J. Res. Pers. 53, 158-164. doi: 10.1016/j.jrp.2014.10.007

O’Boyle, E. H., Forsyth, D. R., Banks, G. C. \& McDaniel, M. A. (2012). A meta-analysis of the Dark Triad and work behavior: A social exchange perspective. Journal of Applied Psychology, 97(3), 557-579. doi:10.1037/a0025679

O’Boyle, E. H., Forsyth, D. R., Banks, G. C., Story, P. A., \& White, C. D. (2014). A Meta-Analytic Test of Redundancy and Relative Importance of the Dark Triad and Five-Factor Model of Personality. Journal of Personality, 83(6), 644-664. doi:10.1111/jopy.12126

O'Boyle, E. H., Forsyth, D. R. \& O'Boyle, A. S. (2011). Bad apples or bad barrels: An examination of groupand organizational-level effects in the study of counterproductive work behavior. Group \& Organization Management, 36(1), 39-69.

Özsoy, E. (2018). Dark Triad and Counterproductive Work Behaviors: Which of the Dark Triad Traits is More Malevolent? Journal of Business Research-Turk, 10 (4), 742-756.

Paulhus, D. L. \& Williams, K. M. (2002). The Dark Triad of personality: Narcissism, Machiavellianism, and psychopathy. Journal of Research in Personality, 36, 556-563.

Paulhus, D. L., Neumann, C. S. \& Hare, R. D. (2015). Manual for the Self-Report Psychopathy (SRP) Scale. Toronto: Multi-Health Systems.

Penke, L., Denissen, J. J. \& Miller, G. F. (2007). The evolutionary genetics of personality.European Journal of Personality, 21, 549-587.

Perri, F. S. (2011). White-collar criminals: The kinder, gentler offender? Journal of Investigative Psychology and Offender Profiling, 8(3), 217-241.

Pilch, I. \& Górnik-Durose, M. E. (2016). Do we need "dark" traits to explain materialism? The incremental validity of the Dark Triad over the HEXACO domains in predicting materialistic orientation. Personal. Individ. Differ. 102, 102-106. doi: 10.1016/j.paid.2016.06.047.

Raskin, R. N. \& Hall, C. S. (1979). Narcissistic Personality Inventory. Psychological Reports, 45, 590. 
Rauthmann, J. F. (2012). The Dark Triad and interpersonal perception: Similarities and differences in the social consequences of narcissism, Machiavellianism, and psychopathy. Social Psychological and Personality Science, 3, 487- 496.

Ray, J. J. \& Ray, J. A. B. (1982). Some apparent advantages of subclinical psychopathy. Journal of Social Psychology, 117, 135-142.

Resick, C. J., Whitman, D. S., Weingarden, S. M. \& Hiller, N. J. (2009). The bright-side and the dark-side of CEO personality: Examining core self-evaluations, narcissism, transformational leadership, and strategic influence. Journal of Applied Psychology, 94, 1365-1381. doi:10.1037/ a0016238

Reynolds Kueny, C. A., Frankca, E., Shoss, M. K., Headrick, L. \& Erb, K. (2020). Ripple effects of supervisor counterproductive work behavior directed at the organization: using affective events theory to predict subordinates' decisions to enact CWB. Human Performance, 1-23.

Richardson, E. N. \& Boag, S. (2016). Offensive defenses: the mind beneath the mask of the Dark Triad traits. Personal. Individ. Differ. 92, 148-152. doi: 10.1016/j.paid.2015.12.039

Robinson, S. L. \& Bennett, R. J. (1995). A typology of deviant workplace behaviors: a multidimensional scaling study. Academy of Management Journal, 38, 555-572.

Rosenthal, S. A. \& Pittinsky, T. L. (2006). Narcissistic leadership. Leadersh. Q. 17, 617-633. doi: 10.1016/j.leaqua.2006.10.005

Şahin, F., Çetin, F. The Mediating Role of General Self-Efficacy in the Relationship Between the Big Five Personality Traits and Perceived Stress: A Weekly Assessment Study. Psychol Stud 62, 35-46 (2017). https://doi.org/10.1007/s12646-016-0382-6

Scherer, K. R. (1997). Profiles of emotion-antecedent appraisal: testing the-oretical predictions across cultures. Cognition and Emotion, 11, 113-150.http://dx.doi.org/10.1080/026999397379962

Schmidt, F. L., Shaffer, J. A. \& Oh, I. S. (2008). Increased accuracy for range restriction corrections: Implications for the role of personality and general mental ability in job and training performance. Personnel Psychology, 61, 827-868. doi:10.1111/j.1744-6570.2008.00132.x

Schwarzkopf, K., Straus, D., Porschke, H., Znoj, H., Conrad, N., Schmidt- Trucksäss, A., et al. (2016). Empirical evidence for a relationship between narcissistic personality traits and job burnout. Burn. Res. 3 , 25-33. doi: 10.1016/j.burn.2015.12.001

Siller, H. \& Cibak, L. (2016). Korruption und ihre gesamtwirtschaftliche Bedeutung, Em: KriminalistikOsterreich, 1/2016, ISBN: 978-3- 7832-0804-7.

Skarlicki, D. P. \& Folger, R. (1997). Retaliation in the workplace: the roles of distributive, procedural, and interactional justice. Journal of Applied Psychology, 82, 434-443. 
Skinner, N. F. (1988). Personality correlates of Machiavellianism: VI. Machiavellianism and the psychopath. Social Behavior and Personality: An International Journal, 16, 33-37.

Sykes, G. M., \& Matza, D. (1957). Techniques of neutralization: A theory of delinquency. American Sociological Review, 22, 664-670. https://doi.org/10.2307/2089195

Smith, S. F. \& Lilienfeld, S. O. (2013). Psychopathy in the workplace: The knowns and unknowns. Aggression and Violent Behavior, 18, 204-218.

Soyer, R. B., Rovenpor, J. L., Kopelman, R. E., Mullins, L. S. \& Watson, P. J. (2001). Further assessment of the construct validity of four measures of narcissism: Replication and extension. Journal of Psychology: Interdisciplinary and Applied, 135, 245-258. doi:10.1080/00223980109603695

Spain, S., Harms, P. \& LeBreton, J. (2014). The dark side of personality at work. Journal of Organizational Behavior, 35, 41-60. https://doi.org/10.1002/job.1894.

Spector, P. E. \& Fox, S. (2005). A model of counterproductive work behavior. In S. Fox \& P. E. Spector (Eds.), Counterproductive workplace behavior: Investigations of actors and targets (pp. 151-174). Washington, DC: APA.

Spector, P. E., Fox, S., Penney, L. M., Bruursema, K., Goh, A. \& Kessler, S. (2006). The dimensionality of counterproductivity. Journal of Vocational Behavior, 68, 446-460.

Spector, P. E. \& Fox, S. (2010). Theorizing about the deviant citizen: An attributional explanation of the interplay of organizational citizenship and counterproductive work behavior. Human Resource Management Review, 20(2), 132-143.

Spence, J. R., Ferris, D. L., Brown, D. J., \& Heller, D. (2011). Understanding daily citizenship behaviors: A social comparison perspective. Journal of Organizational Behavior, 32(4), 547-571.

https://doi.org/10.1002/job.738

Stolarski, M., Czarna, A. Z., Malesza, M. \& Szyma'nska, A. (2017). Here and now: Sociosexuality mediates the associations between Dark Triad and Time Perspectives (in females). Personality and Individual Differences, 111, 119-123.

Treviño, L. K., Brown, M. \& Hartman, L. P. (2003). A qualitative investigation of perceived executive ethical leadership: Perceptions from inside and outside the executive suite. Human Relations, 56(1), 5-37

Van Geel, M., Toprak, F., Goemans, A., Zwaanswijk, W. \& Vedder, P. (2017). Are youth psychopathic traits related to bullying? Meta-analyses on callous-unemotional traits, narcissism, and impulsivity. Child Psychiatry \& Human Development, 48, 768-777.

Volmer, J., Koch, I. K. \& Göritz, A. S. (2016). The bright and dark sides of leaders' Dark Triad traits: Effects on subordinates' career success and well-being. Personality and Individual Differences, 101, 413-418. 
Wagner, B. M., Compas, B. E. \& Howell, D. C. (1988). Daily and major life events: A testof an integrative model of psychosocial stress. American journal of communitypsychology, 16(2), 189-205. http://dx.doi.org/10.1007/BF00912522

Weiss, H. M. \& Cropanzano, R. (1996). Affective events theory: A theoretical discus-sion of the structure, causes and consequences of affective experiences at work. Research in Organizational Behavior, 18, 174.

Williams, K. M., McAndrew, A., Learn, T., Harms, P. \& Paulhus, D. L. (2001, August). The Dark Triad returns: Entertainment preferences and antisocial behavior among narcissists, Machiavellians, and psychopaths. Poster session presented at the annual convention of the American Psychological Association, San Francisco, CA.

Williams, K. M., Paulhus, D. L., \& Hare, R. D. (2007). Capturing the Four-Factor Structure of Psychopathy in College Students Via Self-Report. Journal of Personality Assessment, 88(2), 205219. doi:10.1080/00223890701268074

Wu, J., \& Lebreton, J. M. (2011). Reconsidering the dispositional basis of counterproductive work behavior: The role of aberrant personality. Personnel Psychology, 64(3), 593-626. https://doi.org/10.1111/j.1744-6570.2011.01220.x

Ying L, \& Cohen A. (2018) Dark triad personalities and counterproductive work behaviors among physicians in China. Int J Health Plann Mgmt. pp. 1-14. https://doi.org/10.1002/hpm.2577

Zhao H, Zhang H \& Xu Y. (2016) Does the dark triad of personality predict corrupt intention? The mediating role of belief in good luck. Front Psych. p. 7:608. https://doi.org/10.3389/fpsyg.2016.00608

\section{Figures}




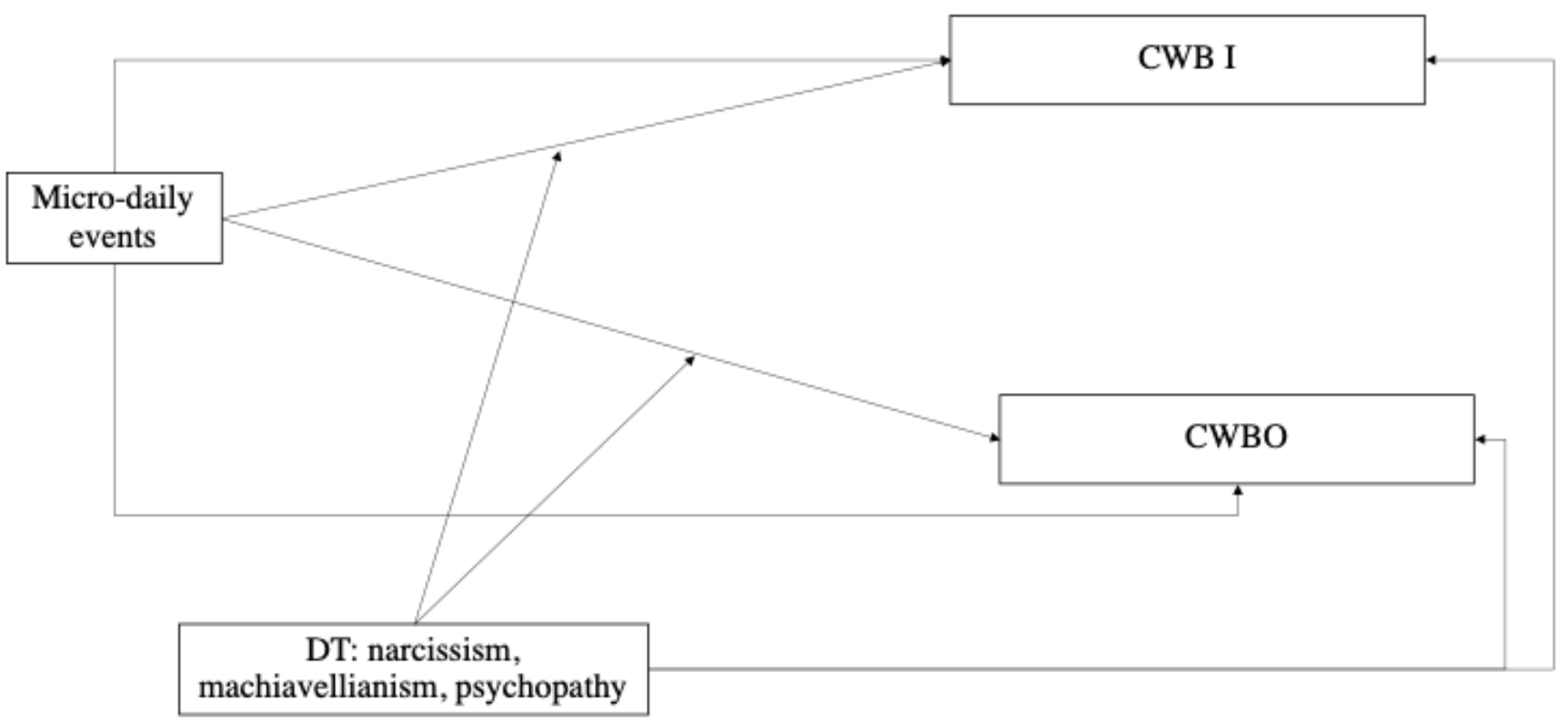

\section{Figure 1}

Conceptual model: the moderating role of DT between micro-daily events and CWB's.

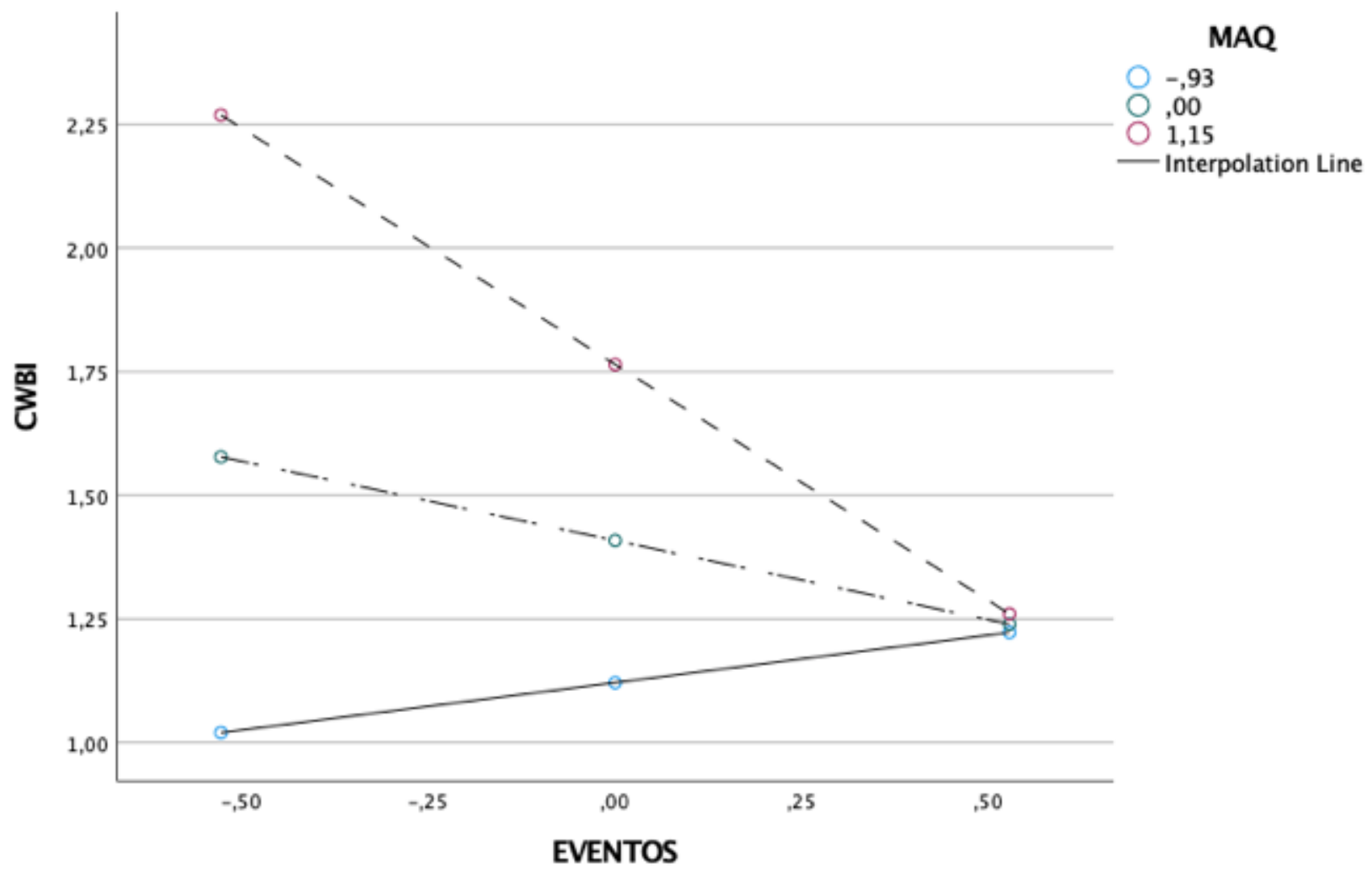


Figure 2

The moderating effect of machiavellianism in the relationship between micro-daily events and CWBI.

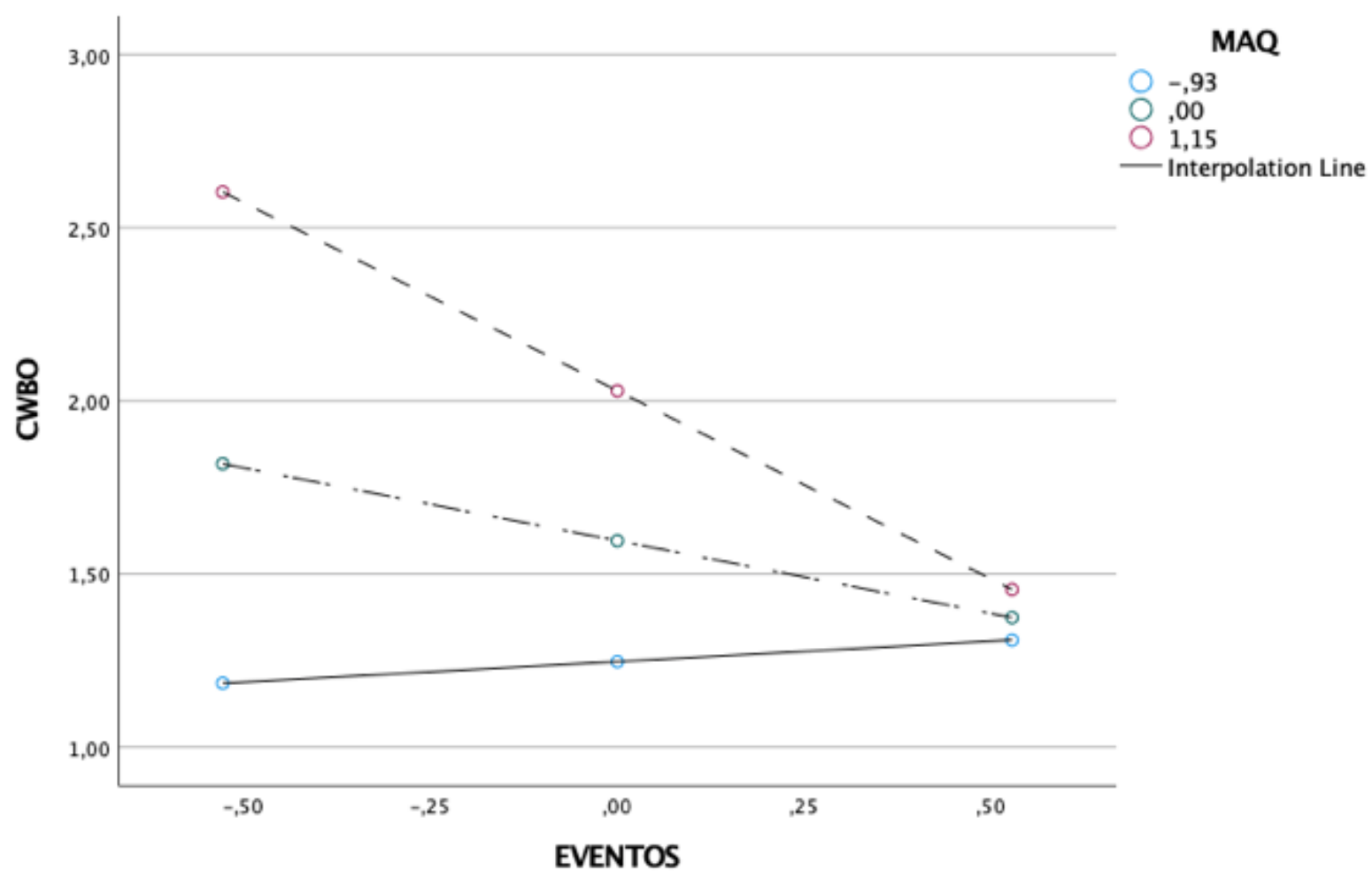

Figure 3

The moderating effect of machiavellianism in the relationship between micro-daily events and CWBO. 


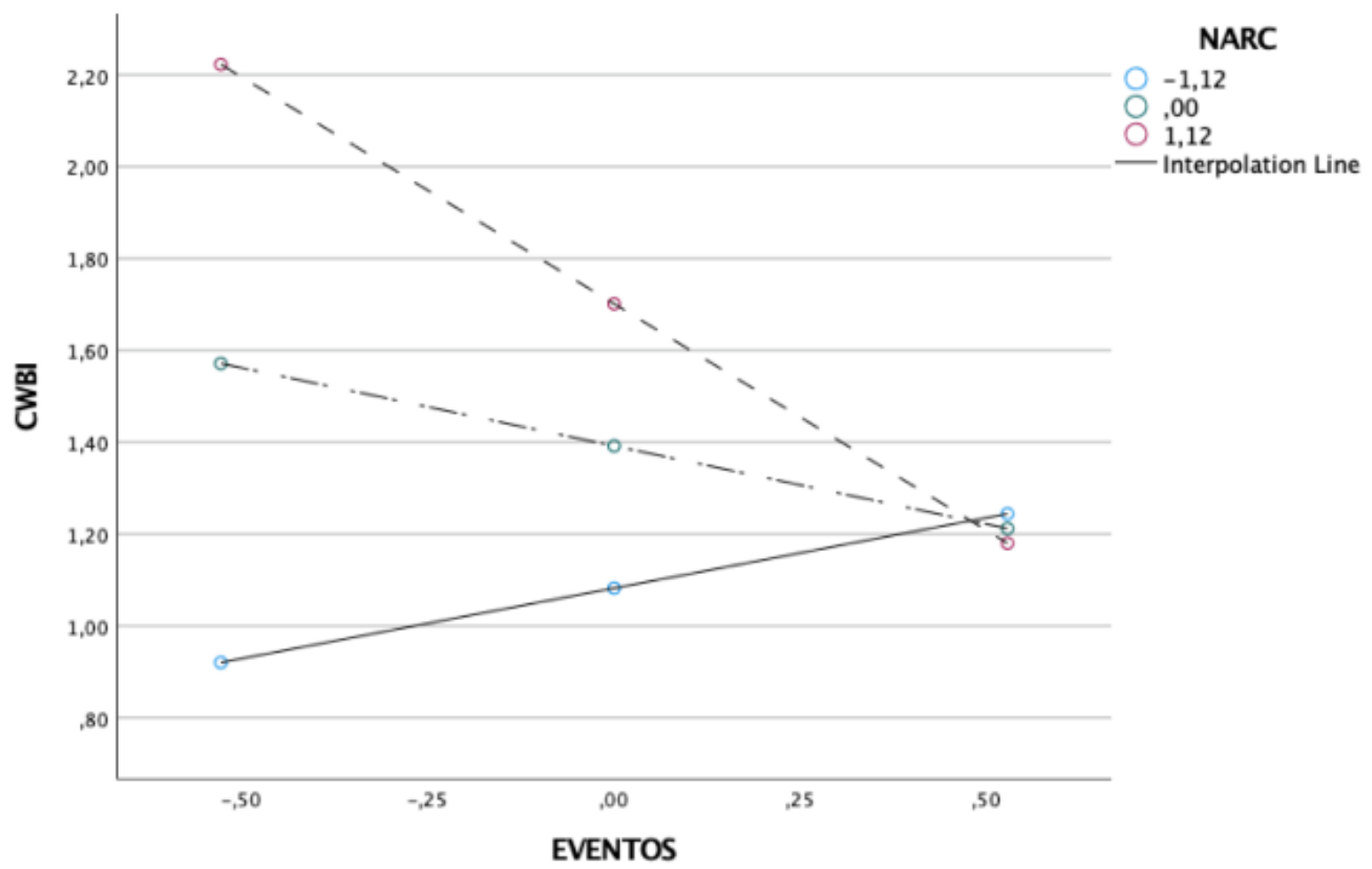

Figure 4

The moderating effect of narcissism in the relationship between micro-daily events and CWBI.

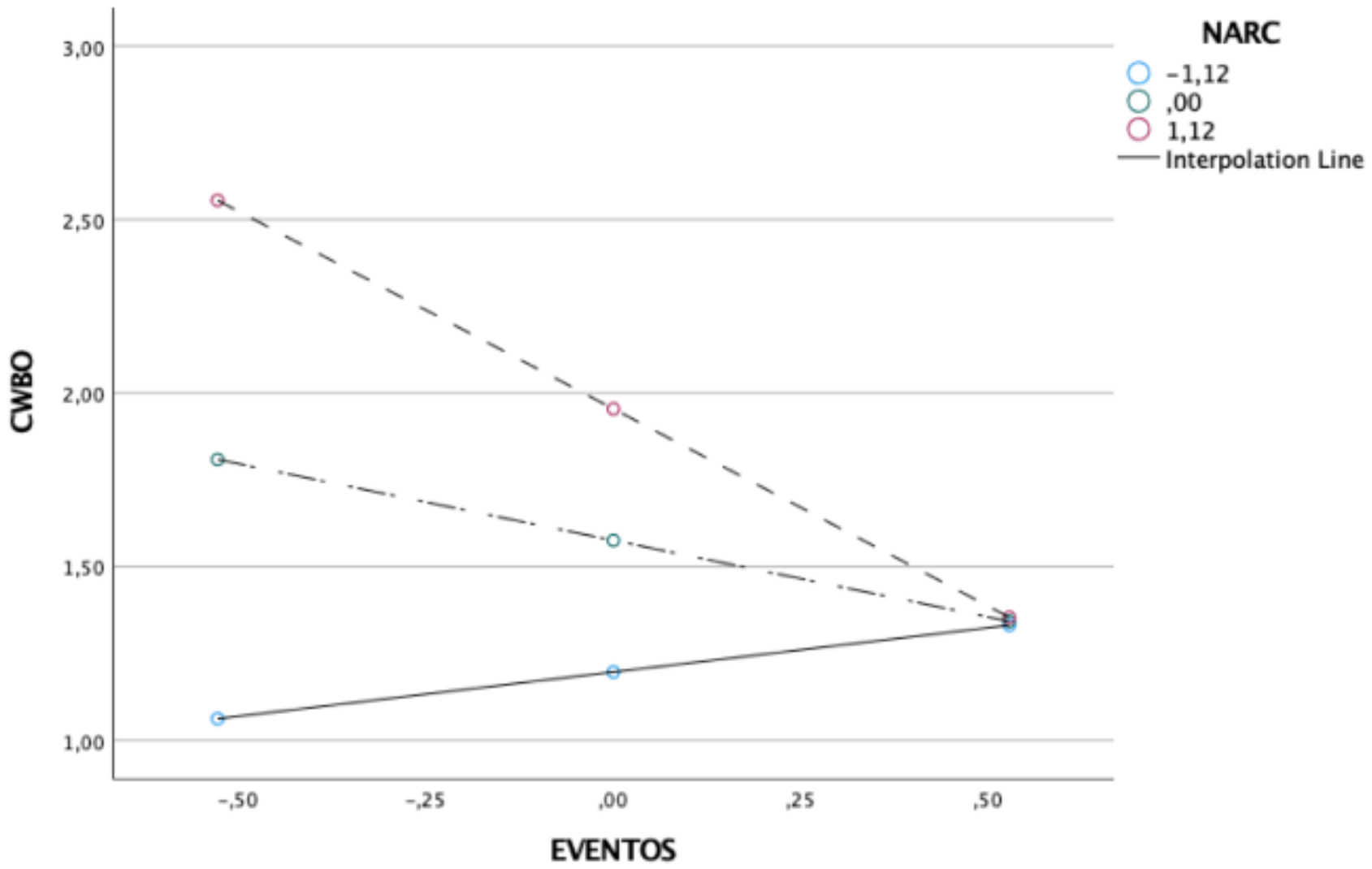

Page 29/31 


\section{Figure 5}

The moderating effect of narcissism in the relationship between micro-daily events and CWBO.

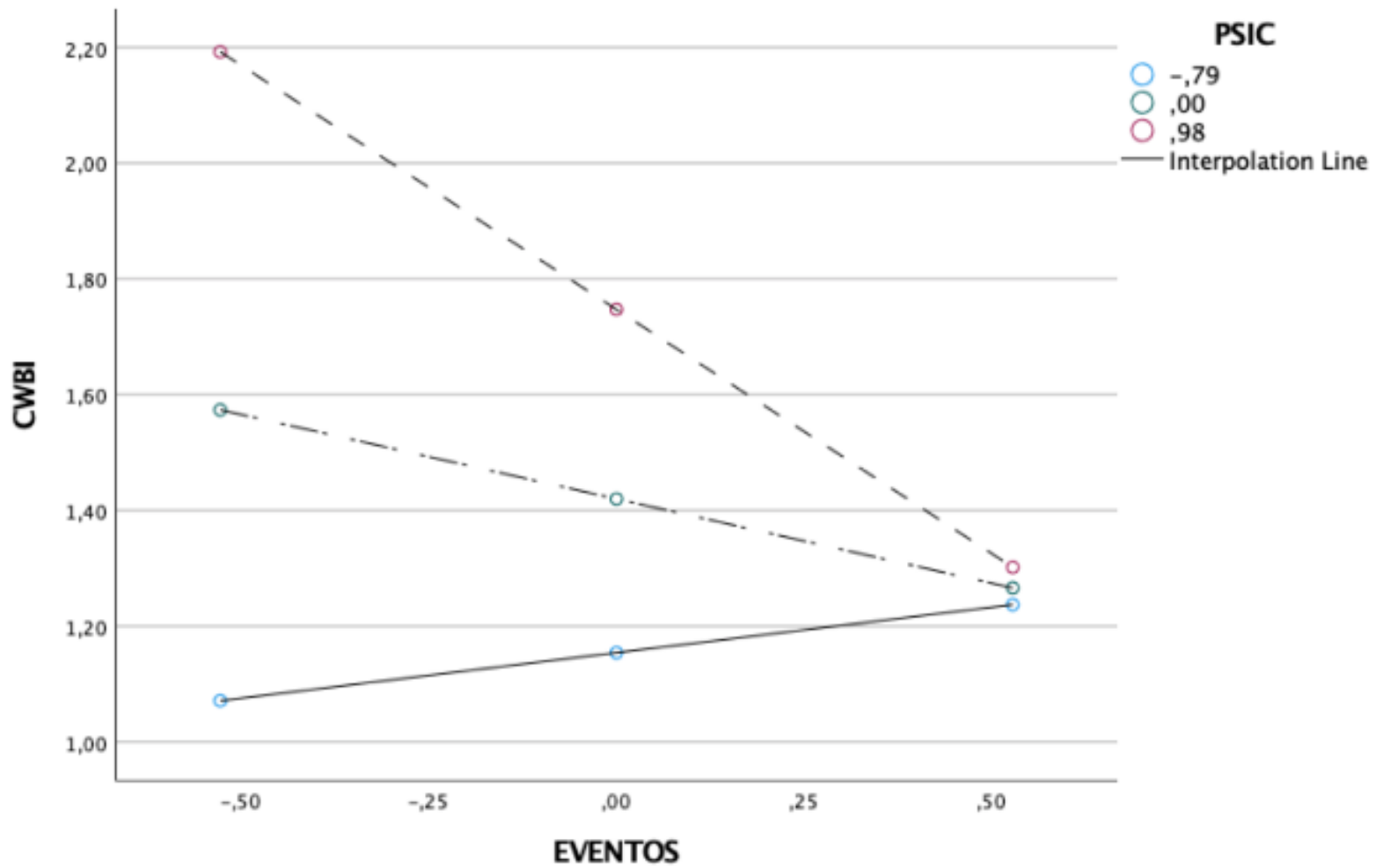

\section{Figure 6}

The moderating effect of psychopathy in the relationship between micro-daily events and CWBI. 


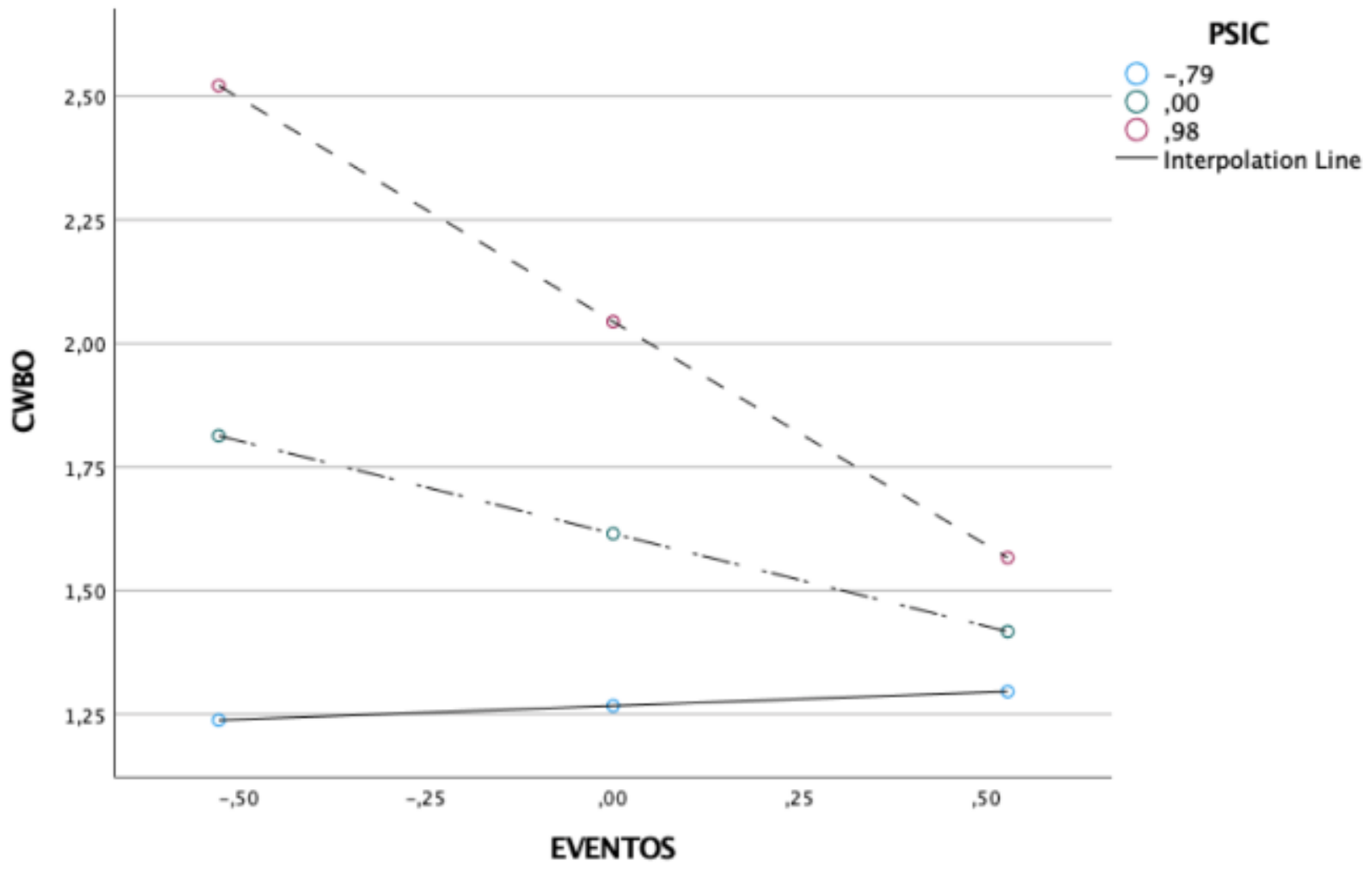

Figure 7

The moderating effect of psychopathy in the relationship between micro-daily events and CWBO. 